\title{
世界における生産分配を考慮した 日本の鉄鋼生産量の推計
}

\author{
河瀬＼cjkstart玲奈 $1 *$ ・松岡 譲2 \\ 1京都大学工学研究科都市環境工学専攻（†615-8540 京都府京都市西京区京都大学桂Cクラスター）助教 \\ * E-mail: rkawase@athehost.env.kyoto-u.ac.jp \\ 2京都大学工学研究科都市環境工学専攻（†615-8540 京都府京都市西京区京都大学桂Cクラスター）教授
}

\begin{abstract}
財の貿易に関するシナリオおよび鉄鋼消費の見通しやスクラップ余剩を生産決定因子とする製鋼法選択 シナリオなどを設定することで，世界の生産動向に複数の想定をおき，その条件下で日本の鉄鋼生産量が 取り得る幅について，製鋼法別に2012年から2050年までの期間について推計を行った.

その結果，最大值をとるのはスクラップを国内で最大限消費することを想定するシナリオであり，電炉 鋼の増加により2035年に1.49億トンになった後，2050年には1.20億にまで減少する．最小值をとるのは電 炉生産における技術進歩を想定し，かつ，鉄鋼の需給バランスを取るように生産調整を行うシナリオであ り，2050年にむけて徐々に減少し4,400万となった。
\end{abstract}

Key Words : Steel production, steel making process selection scenario, good trade scenario

\section{1. はじめに}

日本における低炭素社会の構築において，エネルギー 集約素材である鉄鋼の生産量推計は必須の課題である. 例えば，長期エネルギー需給見通し ${ }^{1)} の$ 検討や2050年に 向けた2013年以降の対策・施策に関する報告書2)におい て, 鉄鋼生産量はエネルギ一需要量や二酸化炭素排出量 を決定する重要な要素として位置づけられている。世界 においても同様であり，鉄鋼需要の増加が見込まれてい るが3)，その一方で温室効果ガス削減が求められてる状 況下において, どの地域でどれだけの生産を行うかは, 重要な定量的情報である.

世界合計でタると, 需要量=生産量の関係が成り立つ が，各地域においては，需給差は大きく異なる．鉄鋼は 貿易財であり，鉄鋼を投入し生産される財もまた貿易財 であるものが多い。日本においては，2013年は1.11億卜 ンの粗鋼生産量に対し，見掛け消費量は6,880万トン

(以下，消費量），国内ストックへの追加量（以下，需 要量) は4,388万トンと, 生産量と需要量には大きな隔 たりがある4)、鉄鋼生産量は国内需要のみならず，世界 の鉄鋼および製品（財）の生産分配に大きな影響を受け る.したがって, 鉄鋼生産量を推計する際には, 鉄鋼や
財の貿易を考慮する必要がある.

世界における財の生産分配においては，コスト最小化 や二酸化炭素排出量の最小化という最適解ではなく，現 存する生産能力が主要因であることがHidalgo et al. ${ }^{5)}$ で指 摘されている. 鉄鋼の主要な生産設備は寿命が長いこと から，一旦建設されると技術が固定してしまう。このこ とが温暖化政策に与える影響は大きい. よって, 長期的 視野にたった整備計画が求められる，粗鋼の生産は，転 炉と電炉に大別することができ，その鉄源としては，銑 鉄，直接還元鉄（DRI），スクラップが挙げられる.こ れら鉄源をそれぞれの炉でどのような比率で配合するか は，技術的制約の他，その地域の鉄源供給状況にもよる. スクラップは，鉄鋼や財の生産工程とストックからの減 耗により発生する。したがって発生量には限界があり, さらにそれをどれだけ回収できるのか，によっても供給 制約がある. スクラップは主に電炉における鉄源となる ことから, 電炉での生産には鉄源供給からの制約が生じ ることとなる.

東ら゙は，物質ストック・フローモデルを構築し世界 を35地域に分類して地域別鉄鋼需要量を推計したが，こ れは地域内ストックへの追加量であり，貿易を含めた鉄 鋼生産量ではない. 同じく世界全体の鉄鋼生産量を推計 
したものとしては， worldsteel ${ }^{6} の$ 報告があるが，地域別 の推計は行っていない. 製鋼法別に推計したものとして は, Hidalgo et al. ${ }^{5}$ があり2030年の世界の鉄鋼生産量（BaU シナリオ）は13億トンと推計されているが，報告值では 2014年においてすでに16億トンに達していることから， 過少評価と言えよう。加えて, 地域分類が11地域となっ ており，日本は単独には扱われていない，また，河瀬ら カがスクラップの最大利用による二酸化炭素排出量削減 の観点から2050年までの推計を行っているが，各地域の 鉄鋼やスクラップの需給状況を考慮して鉄鋼生産量を推 計していないことが課題として挙げられる．地域別製鋼 法別生産量を推計しているのはIEA)であり，各地域の鉄 鋼生産量をまず決定し，その生産量をEnd-use型モデルで 製鋼法別に分配している．転炉と電炉では企業が異なり， それぞれが個別に鉄鋼消費の見通しに基づき鉄鋼生産量 を決定するが，この点について反映されていない．

本研究では，財の貿易に関するシナリオおよび鉄鋼消 費見通しやスクラップ余剩量などを生産決定因子とする 製鋼法選択シナリオなどを設定することで，世界の生産 動向に複数の想定をおき，その条件下で日本の製鋼法別 鉄鋼生産量が取り得る幅について2012年から2050年まで の推計を行うことを目的とする.

なお，鉄鋼は様々な財の生産に利用されるが，その中 でも機械類や輸送機器などの生産には質の高、鋼材が要 求される傾向がある，そのような質の高い鋼材は高炉か らの一貫工程での品質管理のもと生産されることが多い そこで，鉄鋼消費量のうち，質が高く転炉で生産を行う 量を転炉鋼要求量と呼ぶ.

\section{2. シナリオの設定と鉄鋼生産量推計方法}

\section{(1) 推計方法の概要}

世界を35地域に分類し（表-1），それぞれの地域にお ける鉄鋼需要量は所与とし, 財の貿易シナリオ（3種） により，各地域における鉄鋼消費量を決定寸る，転炉鋼 要求量は，技術進歩の違いによる転炉鋼要求シナリオ （2種）を設定し推計する．鉄鋼消費の見通し，転炉鋼 要求量, スクラップ余剩量, および, 鉄鋼需給状況によ り決定される製鋼法選択シナリオ（4種）により，世界 の生産動向に対し，合計24通りの想定をおき，その条件 下で日本の製鋼法別鉄鋼生産量を推計する. 製鋼法は, 転炉と電炉に分類する. 推計期間は，2012年を基準年と し2050年までとする.

鉄鋼需要量は，サービス需要の管理や財ストックの効 率の改善などに加え, ハイテンの導入などの対策がトレ ンド相当で導入されるシナリオの推計值9)(図-1）を用
表-1 世界の地域分類

\begin{tabular}{|c|c|c|}
\hline 地域名 & 地域名 & 地域名 \\
\hline 1 日本 & 13 シンガポール & 25 アメリカ合衆国 \\
\hline 2 中国 & 14 マレーシア & 26 初期EU所属国 \\
\hline 3 韓国 & 15 インドネシア & 27 その他EU所属国 \\
\hline 4 台湾 & 16 フィリピン & 28 西欧附属書I国 \\
\hline 5タイ & 17 アルゼンチン & 29 東欧附属書I国 \\
\hline 6 インド & 18 その他東南アジア & 30 その他ヨーロッパ \\
\hline 7 ベトナム & 19 その他南アジア & 31 その他東欧 \\
\hline 8 トルコ & 20 その他東アジア & 32 オーストラリア \\
\hline 9 カナダ & 21 その他中央アジア & 33 ニュージーランド \\
\hline 10 ロシア & 22 その他オセアニア & 34 南アフリカ共和国 \\
\hline 11 ブラジル & 23 中東諸国 & 35 その他アフリカ \\
\hline 12 メキシコ & 24 その他中南米 & \\
\hline
\end{tabular}
ロその他工業製品
口船舶
口自動車
口その他輸送機器
口土木構造物
口鉄道車両
口機械類
西建築物

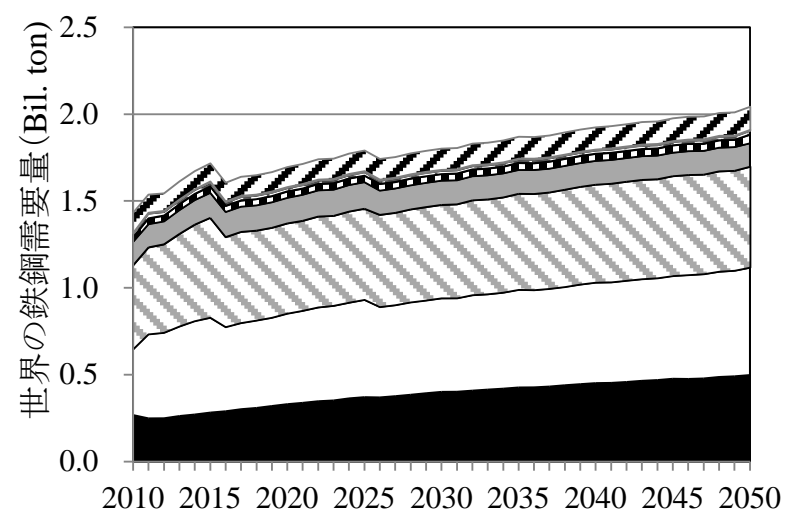

図-1 世界の財別鉄鋼需要量

いる.

財は貿易財と非貿易財に分類され，非貿易財は，鉄鋼 消費量と鉄鋼需要量が等しい. 貿易財は, 機械類, 自動 車 (乗用車, バス十トラック) , 鉄道車両, 船舶, その 他工業製品の分類にて扱い，非貿易財は，建築物，土木 構造物の分類にて扱う.

\section{(2) シナリオの設定}

\section{a）財の貿易シナリオ}

財の貿易シナリオは，鉄鋼の間接輸出入の幅を広くと るため3つを想定した，なお，貿易を想定するのは，貿 易財のみである. 財の貿易シナリオコードとその特徵を 次に示寸.

GT1 : 財ごとの各地域の生産シェアは 2012 年の值で 一定とする.

GT2 : 財ごとの主要生産国は 2012 年の生産量を維持 する. 世界全体の増加分は 2012 年からの需要 の増加量のシェアでその他の地域に按分する.

GT3 : 需要量=生産量になるように収束する. 
2012 年の財の生産量については，自動車は世界自動 車統計年刊 ${ }^{10)}$ ，鉄道車両は鉄道システム事業戦略 ${ }^{11)}$ ，船 舶は造船関係資料 ${ }^{12)}$ ，機械類と他工業製品は Fujimori et al. ${ }^{13)}$ により整備した.

\section{b) スクラップ回収量の設定}

自家発生および財の生産工程において発生する加工ス クラップは，質が安定しており回収が容易であることか ら 100\%の回収を想定する. 老廃スクラップは, 2050 年 の回収率として worldsteel ${ }^{14)}$ が財ごとに設定している目標 值を用い, 基準年から線形的に回収率を変化させる.

\section{c）転炉鋼要求シナリオ}

転炉鋼要求量は，通常の鉄鋼より高機能であるハイテ ンと高級鋼板類とする. 鉄鋼の分類には, 鋼種, 形状や 用途など様々な分類が存在するが，必ずしも製鋼法と一 対一対応する訳ではない，また，一つの財の生産におい て，多様な鋼種，形状の鉄鋼が消費され，財に投入され る鉄鋼ごとに製鋼法が割り当てられている訳でもない. しかしながら一般的に，形状別に条鋼類と鋼板類に大別 した場合，鋼板類の方が質が高いとされ，また用途別で は輸送機器や機械類にて高品質の鉄鋼が消費される.

転炉鋼要求量に対し，電炉での異なる技術進歩を想定す る2つのシナリオを設定する.

B0 : 鉄鋼生産技術を現状水準で固定，つまり，各財の 鉄鋼消費量のうち転炉鋼要求量の比率を固定する B1：技術革新が進み，電炉においても鉄鋼需要量推計 にて想定される機能を有するハイテンや高級鋼板 類の生産が行われ，基準年と比較して各財の鉄鋼 消費量における転炉鋼比率が大幅に減少する.

表-2 に財ごとの鉄鋼消費量における転炉鋼要求量の 比率を基準年と 2050 年の設定值について示す. 基準年 から 2050 年までの補間は線形にて行った。基準年の各 財における鋼板類比率は，過去 20 年間の鋼材品種別用 途別受注 ${ }^{16}$ および特殊鋼の最終用途別需要実態調査 ${ }^{17)}$ り設定した.

表-2 各財の鉄鋼消費量における転炉鋼比率（\%)

\begin{tabular}{|c|c|c|c|c|}
\hline & & 012 & & \\
\hline & 鋼板 & 頁シェア & 転炉鋼 & ナナリオ \\
\hline & & $\begin{array}{c}\text { 転炬鋼 } \\
\text { 比率 }\end{array}$ & B0 & B1 \\
\hline 建築物 & 20 & 10 & 2 & 0 \\
\hline 土木構造物 & 38 & 10 & 3.8 & 0 \\
\hline 機械類 & 80 & 100 & 80 & 55 \\
\hline 自動車 & 98 & 100 & 98 & 55 \\
\hline 鉄道車両 & 80 & 100 & 80 & 55 \\
\hline 船舶 & 87 & 100 & 87 & 55 \\
\hline その他輸送機器 & 60 & 50 & 30 & 15 \\
\hline その他工業製品 & 95 & 30 & 28.5 & 10 \\
\hline
\end{tabular}

品質管理が㛜しい自動車用鋼板においても電炉での 生産が実証段階となっている ${ }^{15)}$. 楽観的見通しでは将来 的に需要側の制約がなくなり，転炉鋼要求 B1 シナリオ の転炉鋼要求量の比率が $0 \%$ なることになる.しかし ながら，その技術の普及には時間も要することから，本 研究では現状比率の約半分相当を設定した.

\section{d）製鋼法選択シナリオ}

製鋼法選択シナリオは，生産量の決定に関係する因子 に対し，どのような選択を行うのかを組み合わせたもの である。世界の鉄鋼消費量を所与とした条件下で，世界 各地域はそれぞれ製鋼法選択シナリオに基づいて製鋼法 別に生産量を決定する.

生産量の決定に関係する因子は5つあり，(1)参照する 鉄鋼消費量見通し，(2)転炉鋼生産における生産地域の数

（転炉鋼を生産している地域数は2012年では35地域中26 地域），(3転炉鋼の地域内需給バランス考慮の有無（地 域内の転炉鋼生産量と転炉鋼要求量の需給バランス) ,

(4)鉄鋼全量の需給バランス考慮の有無（鉄鋼消費量と鉄 鋼生産量の需給バランス) (5)電炉鋼生産量の決定因子 (鉄鋼消費量見通しか, スクラップ余剒量か) である. これら5つの因子に対する選択を組み合わせ4つの製鋼法 選択シナリオを設定した。

表-3 製鋼法選択シナリオの特徵

\begin{tabular}{|c|c|c|c|c|c|}
\hline \multirow{2}{*}{\multicolumn{2}{|c|}{\begin{tabular}{l|l} 
製鋼法選 & 注目 \\
する \\
択シナリ \\
オコード & 見通 \\
オ
\end{tabular}}} & \multicolumn{2}{|c|}{ 転炉鋼 } & \multicolumn{2}{|r|}{ 電炉鋼 } \\
\hline & & $\begin{array}{l}\text { 生産地 } \\
\text { 域の数 }\end{array}$ & \multicolumn{2}{|c|}{$\begin{array}{c}\text { 需給バラン } \\
\text { スの考慮 }\end{array}$} & 決定因子 \\
\hline F000R0 & 世界 & 不変 & $\begin{array}{l}\text { 無 } \\
\end{array}$ & $\begin{array}{l}\text { 無 } \\
\end{array}$ & 鉄鋼消費量 \\
\hline F010R1SD0 & 地域内 & 不変 & 無 & 無 & スクラップ余剰量 \\
\hline F110R1SD1 & |地域内 & 増加 & 無 & 有 & スクラップ余剩量 \\
\hline F111R1CD1 & 地域内 & 増加 & 有 & 有 & 鉄鋼消費量 \\
\hline
\end{tabular}

注目する見通しでは，例えば世界を注目対象とする場 合，地域内の消費見通しは考慮せず，転炬鋼，電炉鋼々 れぞれで，世界の転炉鋼要求量もしくは鉄鋼消費量の見 通しを元に鉄鋼生産量を決定することを意味する．電炉 鋼生産量で生産決定因子をスクラップ余磻量とする場合, 地域内でのスクラップ余唾量を最小化することを目的関 数とする. ここで, スクラップ余剰量は, スクラップ回 収量から電炉と転炉でのスクラップ消費量を差し引いて 求める. 転炉および電炉でのスクラップ比率の上限はそ れぞれ30\% ${ }^{18)}, 112 \%{ }^{16)}$ とした。

生産量の増減は設備容量の増減を伴い，特に高炉一転 炉生産工程では急激な変化は困難である. そこで, 増減 の幅として，減少については減耗率以上の削減は行わな いこと, 増加については消費見通し相当以上の増加は行 わないこと，を制約として与える. 
(3) 製鋼法選択シナリオの定式化

本節で用いるサフィックスや変数および製鋼法選択シ ナリオで共通して用いる定式化を一覧する.

$r:$ 地域（WLDは世界）

$t:$ 年

$k:$ 誤差の種類を表すサフィックス (整数を取る)

$f l g B_{r}: 2012$ 年に転炉鋼生産がある地域は1をとるフラグ $f l g T X_{r, t}$ : 指標Xに生産量>消費量（もしくは要求量）の 関係が成立している時に 1 であるフラグ

$f l g R X_{r, t}$ : 指標Xの成長率が正の時に 1 であるフラグ

$f l g S_{r, t}$ : スクラップが供給量>消費量の時に 1 である

$$
\text { フラグ }
$$

$O B J$ :目的変数

$R X:$ 指標 $X$ の年変化率

$B O F_{r, t}:$ 転炉鋼生産量

$E A F_{r, t}:$ 電炉鋼生産量

$C R S_{r, t}$ : 鉄鋼生産量

$B O F d_{r, t}:$ 転炉鋼要求量

$B O F d p r_{r, t}:$ 転炉の減耗率

$E A F d p r_{r, t}:$ 電炉の減耗率

$C N S_{r, t}$ : 鉄鋼消費量

$S C R_{r, t}$ : スクラップ余剩量

$e r_{k, r, t}:$ 誤差

flgRXは，指標となるXが需要量や消費量であることか ら, 財の貿易シナリオや転炉鋼要求シナリオを決定した 段階で算出される. そのため, 製鋼法選択シナリオにお いて, 生産量を推計する際には所与である。一方, flgTXやflgSは, 現状と次期の量との比較であることから, 一期ごとに内生的に計算される.

すべての地域, 年について, 式(1)〜(7)が成立する.

$$
\begin{aligned}
& C R S_{r, t}=B O F_{r, t}+E A F_{r, t} \\
& C R S_{" W L D ", t}=\sum_{r} C R S_{r, t} \\
& B O F_{" W L D ", t} \geq \sum_{r} B O F d_{r, t} \\
& B O F_{r, t} \geq B O F_{r, t-1} *\left(1-B O F d p r_{r, t}\right) \\
& E A F_{r, t} \geq E A F_{r, t} *\left(1-E A F d p r_{r, t}\right) \\
& B O F_{" W L D ", t}-\sum_{r} B O F d_{r, t}=e r_{" 1 ", t} \\
& O B J_{t}=\sum_{k} \sum_{r} e r_{k, r, t}^{2} \rightarrow \min \quad, \quad \forall t
\end{aligned}
$$

さらに，転炉鋼，電炉鋼それぞれにおいて，flgTX=1 の関係が成立している地域においては, 生産量が消費量 を下回らないという式(8)と式(9)の制約をおく.

$$
\begin{aligned}
& \text { BOF }_{r, t} \geq \text { BOFd }_{r, t} \quad, \quad\left(\text { figTBOF }_{r, t}=1\right) \\
& \text { CRS }_{r, t} \geq \text { CNS }_{r, t} \quad, \quad\left(\text { figTCRS }_{r, t}=1\right)
\end{aligned}
$$

以下a)〜d) 項では，式(1)〜(9)以外の定式化について記 載する. フラグにより場合分けで定式化が行われていな い変数については, 式(4)もしくは式(5)が定式化となる.

a) FOOROシナリオの定式化

世界の消費見通しを参照するので，指標Xは転炉鋼で は世界の転炉鋼要求量, 電炉鋼では世界の鉄鋼消費量と なる. 要求量や消費量の年変化率に応じて生産量を決定 する（式(10)式(11)）。また, 需給バランスは考慮しな いが，生産量を大きく変化させないという式(12)を制約 として与える.

$$
\begin{aligned}
& f l g B=f^{\prime g R B O F d_{" W L D ", t}}=1 \text { の場合 } \\
& B O F_{r, t} \leq B O F_{r, t-1} \cdot R B O F d_{" W L D ", t} \\
& \operatorname{flgRCRS}_{\text {"WLD",t }}=1 \text { 場合 } \\
& C R S_{r, t} \geq C R S_{r, t-1} \cdot R_{C R S{ }^{W L D ", t}} \\
& E A F_{r, t}-E A F_{r, t-1}=e r{ }^{2 ", r, t}
\end{aligned}
$$

\section{b) F010R1SD0 シナリオの定式化}

転炉鋼生産地域の数が不変のため, 基準年の転炉鋼生 産地域は非生産地域の消費分も生産しようする. ただし 生産決定においては，地域内の転炉鋼消費見通しを参照 するため, 式(13)で生産量を決定する. 電炉鋼はスクラ ップ余剒が発生している地域で生産が大きく増加する (式(14), 式(15)）。スクラップ余剩が発生していない地 域においても，図-1に示される通り，世界の鉄鋼消費量 は増加しているので一期前の生産量は下回らないという 選択を行う（式(16)）。

$$
\begin{aligned}
& f l g B=\operatorname{flgRBOFd}_{r, t}=1 \text { の場合 } \\
& B O F_{r, t} \geq B O F_{r, t-1} \cdot R B O F d_{r, t} \\
& f \operatorname{lgS}_{r, t}=\text { flgRCRS }_{r, t}=1 \text { 場合 } \\
& E A F_{r, t} \geq E A F_{r, t-1} \cdot R C R S_{r, t} \\
& \text { flgS }_{r, t}=1, f_{\text {flgRCRS }} \text { r,t }=0 \text { の場合 } \\
& E A F_{r, t} \geq E A F_{r, t-1} \\
& f l g S_{r, t}=0, f \lg R C R S_{r, t}=1 の \text { 場合 } \\
& E A F_{r, t}=E A F_{r, t-1} \\
& C R S_{r, t}-C N S_{r, t}=e r^{1 "}{ }^{\prime \prime}, r, t
\end{aligned}
$$




$$
S C R_{r, t}=e r_{* 4 ", r, t}, \quad\left(f l g S_{r, t}=1\right)
$$

\section{c）F110R1SD1シナリオの定式化}

転炉鋼を生産する地域の増加を想定するので， $\mathrm{flgB}=0$ の地域の定式化が存在する（式(19)）。F010R1SD0シナ

リオと同じく $f \operatorname{flg} S=1$ の地域で電炉鋼の生産量を積極的 に増加させる（式(22), 式(23)）。また，鉄鋼消費量で需 給バランスを考慮するので，式(26)にて誤差を定義する．

$$
\begin{aligned}
& f \lg B=0, f_{\operatorname{lgRBOFd}} d_{r, t}=1 \text { 場合 } \\
& B O F_{r, t} \geq B O F_{r, t-1} \\
& f l g B=f l g R B O F d_{r, t}=0 \text { の場合 } \\
& B O F_{r, t}=B O F_{r, t-1} \\
& B O F_{r, t} \geq B O F_{r, t-1} \\
& f \lg S_{r, t}=f^{\prime g R C R S_{r, t}}=1 \text { の場合 }
\end{aligned}
$$

$$
E A F_{r, t} \geq E A F_{r, t-1}
$$

flgS $_{r, t}=$ flgRCRS $_{r, t}=1$, flgTCRS $_{r, t}=0$ の場合

$$
E A F_{r, t}=E A F_{r, t-1} \cdot R C R S_{r, t}
$$

$f \lg S_{r, t}=f^{\prime g T C R S} S_{r, t}=1, f \operatorname{flg} R C R S_{r, t}=0$ の場合

flgS $_{r, t}=$ flgTCRS $_{r, t}=0$ の場合

$$
E A F_{r, t}=E A F_{r, t-1}
$$

flgS $_{r, t}=0, f_{\lg R C R S_{r, t}}=$ flgTCRS $_{r, t}=1$ 場合

$$
E A F_{r, t} \leq E A F_{r, t-1}
$$

$C R S_{r, t}-C N S_{r, t}=e r_{"^{\prime \prime}, r, t}$

$$
S C R_{r, t}=e r{ }^{4 ", r, t}, \quad\left(\text { flgS }_{r, t}=1\right)
$$

\section{d）F111R1CD1シナリオの定式化}

転炉鋼，鉄鋼消費量の需給バランスを考慮するので,

flgTの值が生産の増減を決定する重要な因子となる（式 (29) (34)）. 式(7)の目的関数にて, 式(6)の誤差に加え, 各地域において式(35)と式(36)にて定義される需給差が考 慮され，世界全体で需給バランスが取れるよう生産量が 調整される.

$$
\begin{aligned}
& f l g B=0 \text { の場合 } \\
& B O F_{r, t} \geq B O F_{r, t-1} \cdot R B O F d_{r, t} \\
& \text { ただし, } B O F_{r, t} \leq B O F d_{r, t} \\
& f \lg B=f^{\prime g R B O F d} d_{r, t}=\operatorname{flgTBOF}_{r, t}=1 \text { 場合 } \\
& B O F_{r, t} \leq B O F_{r, t-1} \\
& f \lg B=\operatorname{flgRBOFd}_{r, t}=1, \operatorname{flgTBOF}_{r, t}=0 \text { の場合 } \\
& B O F_{r, t} \geq B O F_{r, t-1}
\end{aligned}
$$

$$
\begin{aligned}
& f l g B=1, f^{\prime g R B O F d_{r, t}}=f_{\operatorname{lgTBOF}} \mathrm{F}_{r, t}=0 \text { の場合 } \\
& B O F_{r, t}=B O F_{r, t-1} \\
& \text { flgRCRS }_{r, t}=\text { flgTCRS }_{r, t}=1 \text { の場合 } \\
& E A F_{r, t}=E A F_{r, t-1} \\
& \text { flgRCRS }_{r, t}=1, f^{\prime l g T C R S} S_{r, t}=0 \text { の場合 } \\
& E A F_{r, t}=E A F_{r, t-1} \cdot R C R S_{r, t} \\
& \text { flgRCRS }_{r, t}=\text { flgTCRS }_{r, t}=0 \text { の場合 } \\
& E A F_{r, t} \geq E A F_{r, t-1} \\
& C R S_{r, t}-C N S_{r, t}=e r_{{ }^{3 "}, r, t} \\
& B O F_{r, t}-B O F d_{r, t}=e r_{n ", r, t}
\end{aligned}
$$

\section{3. 結果と考察}

鉄鋼生産量を決定する大きな要因となる鉄鋼消費量を 財の内訳とともに示し，うち転炉鋼要求量については, 日本とともに世界についてもを示寸．次に，これらの情 報をもとに推計される製法別鉄鋼生産量の推計結果を示 し，製鋼法選択シナリオごとの推計結果の特徵について 考察を行う.

\section{(1) 鉄鋼消費量}

日本の鉄鋼消費量は，いずれの財の貿易シナリオにお いても減少しており，2050年の鉄鋼消費量は4,327〜 5,279 万トンとなる（図-2）。非貿易財はいずれのシナリオも 同量のため，貿易財の鉄鋼消費量がシナリオごとの差の 原因となる.

$$
\begin{aligned}
& \text { - 建築物年年構造物 } \\
& \text { 口機械類回自動車 } \\
& \text { 口船舶 口その他輸送機器 } \\
& \text { 口その他工業製品 }
\end{aligned}
$$

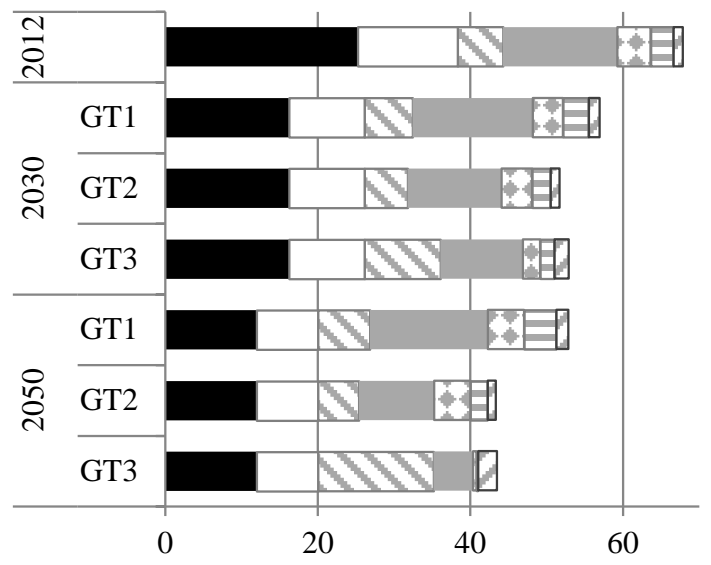

鉄鋼消費量 (MT)

図-2 財別鉄鋼消費量 
GT1シナリオでは，貿易財はやや増加しているが，非 貿易財の中でも特に建築物が大きく減少しているために, 合計では減少となっている，貿易財は，2012年の世界の 財別シェアを固定しているため，これらの財は財の固有 単位では増加していても, 財一単位あたりの物質原単位 が減少しており，これが貿易財の鉄鋼消費量が大きく増 加していない原因となっている.

GT2とGT3シナリオは，財の内訳は異なるものの，合計 はほとんど同じである，GT2シナリオでは自動車や船舶 が多く機械類が少ないのに対し，GT3では逆転している. また，GT3シナリオでは，2050年には需給バランスをと るシナリオであるため, 需給差が解消されている.

\section{(2) 転炉鋼要求量}

\section{a）日本の転炉鋼要求量}

転炉鋼要求量に大きな影響を与えるのは機械類や輸送 機器による鉄鋼消費量であるが，図-2に示される通り鉄 鋼消費量は減少しており, 転炉鋼要求量も横ばい, もし くは減少となっている.

転炉鋼要求量の変化率は，B0のGT1シナリオでは期間 を通してー0.1〜 $0 \%$ であり, 転炉鋼要求量はほぼ横ばい であった（表-4）. B0の GT3シナリオとB1のGT1シナリ オでは，変化率に大きな差はない. B1シナリオでは， 転炉鋼比率の減少のため, 転炉鋼要求量の変化率は $1.9 \% /$ 年以上となっており, 減耗率相当の変化率であ る.つまり，電炉鋼生産における技術革新を見込み，か つ，日本の転炉鋼国内消費のみを考えるのであれば，転 炉は徐々に停止し，電炉で賄うことが可能であることが 示された.

表-4 転炉鋼要求量の変化率

\begin{tabular}{|c|c|c|c|c|c|c|}
\hline & \multicolumn{5}{|c|}{ 転炉鋼要求量変化率（\%/年） } & \\
\hline 転炉鋼要求シナリオ & & B0 & & & B1 & \\
\hline 財の貿易シナリオ & GT1 & GT2 & GT3 & GT1 & GT2 & GT3 \\
\hline $2012-2030$ & -0.1 & -1.1 & -1.1 & -1.3 & -2.3 & -2.3 \\
\hline $2030-2050$ & 0.0 & -0.7 & -1.2 & -1.2 & -1.9 & -2.2 \\
\hline
\end{tabular}

\section{b）世界の転炉鋼要求量}

日本の粗鋼輸出比率は 386\%であり, 高級鋼板類の比 率が高く 9)，世界市場に鉄鋼を供給している．転炉鋼生 産においては，世界の転炉鋼要求量も決定因子である.

転炉鋼要求量は，高級鋼板類に転炉鋼比率を乗じたも のとハイテンのうち量の多いものにて定義されるが，す ベての財において推計期間中，全体として量が多いのは 高級鋼板類であり，転炉鋼要求量を決定する因子となっ た.

転炉鋼要求量は，機械類や輸送機器による鉄鋼消費量 に影響を受けるが，鉄鋼消費量（世界においては鉄鋼消
費量と等しい）全体に占めるこれらの財のシェアは 2012 年から 2050 年にかけて 45\%から 40\%まで徐々に減 少する. 転炉鋼要求量は B0 シナリオではほぼ横ばいで あり，B1シナリオでは転炉鋼要求量が B0 シナリオと比 較して減少しているが，その削減率は 2050 年で 32\%で ある. 2012 年には鉄鋼生産量に占める転炉鋼の割合は $71 \%$ であるが，2050 年には転炉鋼要求量が鉄鋼生産量に 占める割合は $25 \%$ にまで減少する（B1 シナリオ）.

転炉鋼要求量は，B0 シナリオの 2050 年においても現 状の転炉鋼生産量を超えることはなく, 転炉鋼要求量と なるまで現存の転炉鋼の生産能力を徐々に停止させるこ とが可能であることが示された.

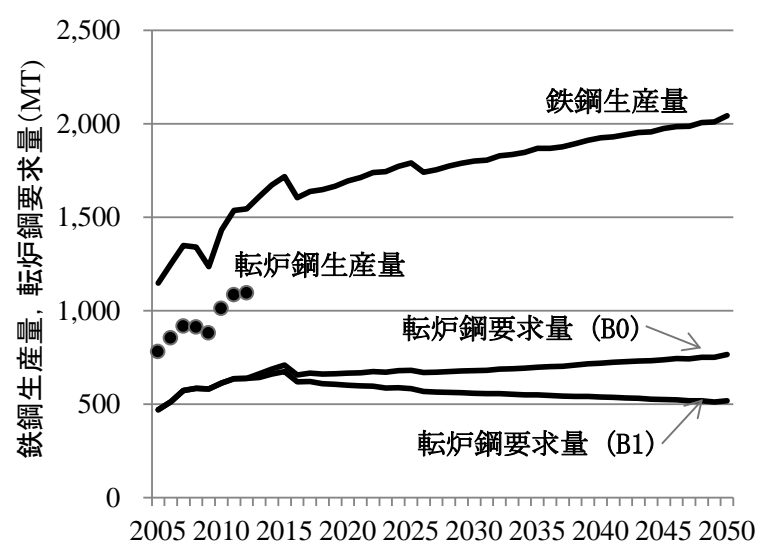

図-3 世界の鉄鋼生産量および転炉鋼要求量

\section{(3) 鉄鋼生産量}

\section{a) 鉄鋼生産量}

シナリオの組み合わせ全 24 通りの推計結果より日本 の鉄鋼生産量の幅を図-4 に示す. 2012 年には 1.07 億卜 ンであった生産量は，2035 年に 1.49 億トンにまで達す るシナリオもあるが, 2050 年には最大 1.2 億トンにまで 減少し, 現状とあまり変わらない生産量となっている. 幅の下限ではほぼ減耗率に従って減少しており，2050 年には需給バランスが成立する程度の 4,327 万トンとな り，59\%の減少となる.

財の貿易シナリオと転炉鋼要求シナリオの違いにより 多少順序は入れ替わるものの，全体として鉄鋼生産量は, 製鋼法選択シナリオが決定要因となった. 図-4に示され る幅の中で上から順に，F010R1SD0，F000R0，

F110R1SD1，F111R1CD1シナリオの線が多かった.

F010R1SD0シナリオは，転炉鋼も電炉鋼も需給バラン スを取ることを考慮しないため，世界全体の鉄鋼消費量 が増加している条件下では，鉄鋼生産を減少させるイン センティブが働かない，そのため，鉄鋼生産量が製鋼法 選択シナリオの中では最も大きくなる．ただし，2035年 以降は，他の地域の鉄鋼生産量増加の影響を受けて，減 少がみられる．2035年までは大きく上昇するにも関わら 


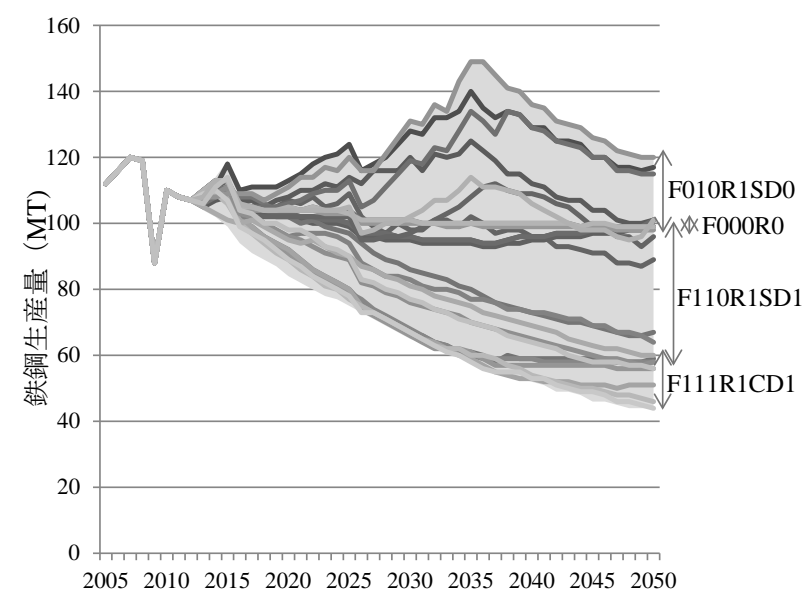

図-4 鉄鋼生産量の幅

ず，それ以降減少しているが，これは，2035年頃から途 上国においてもスクラップ発生量が多くなり電炉鋼生産 量を増加させることにより，相対的に日本における優位 性が低くなるためである.

F000R0シナリオでは，世界の各地域がすべて世界の 消費動向を参照して生産量を決定するため，世界におけ る生産構造は，基準年と大きくは変わらない．また需給 バランスも考慮しないため, 一期前との変化が大きくな いような生産決定を行うため, あまり変化がない.

F110R1SD1では，転炉鋼生産地域が増加寸ることに加 えて，鉄鋼消費量について需給バランスを取ろうとする ため，生産量を増加させるインセンティブが働かず，鉄 鋼生産量は緩やかに減少する。

F111R1CD1は，転炉鋼，鉄鋼ともに需給バランスを取 るシナリオである，日本の鉄鋼消費量は，2012年から 2050年に向けて緩やかに減少していく.

\section{b) 製鋼法別生産量}

シナリオのすべての組み合わせを考えた場合，自動車 や機械類は最終製品であり，鉄鋼は素材であるという違 いはあるものの，財の一つである，したがって，世界全 体の将来シナリオを考えた場合，財貿易のシナリオと製 鋼法選択シナリオに適合しやすい組み合わせがあると考 えられる，そこで，以下においては，製鋼法選択シナリ オにそれぞれ一つの財貿易シナリオを 1 対 1 対応させて, 考察を行う.

製鋼シナリオ法選択シナリオと財貿易シナリオの組み 合わせは，F000R0 シナリオは世界が世界全体での動向 から生産を決定することから GT1 を, F010R1SD0 と F110R1SD1 シナリオは転炉鋼を需給バランスを考慮しな いシナリオであり地域内の技術優位性を維持しょうとす るシナリオであることから GT2 を, F111R1CD1 シナリ オは財の需給バランスをとる GT3 と組み合わせる.

転炉鋼要求シナリオが B0の場合を例として考察を行

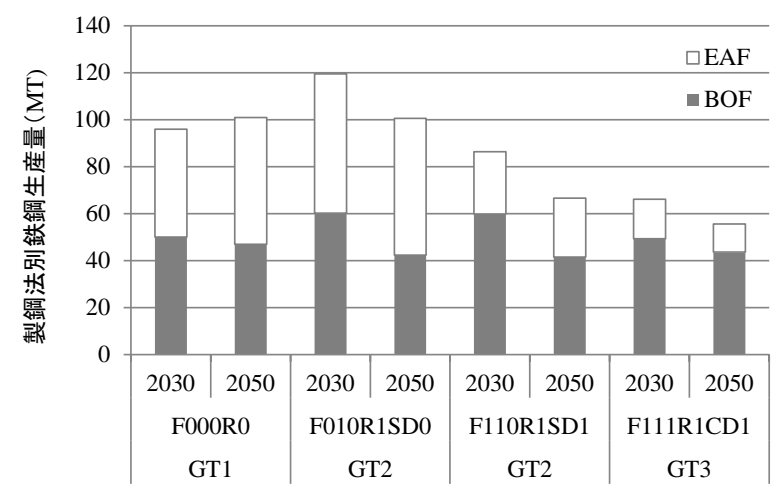

図-5 製鋼法別鉄鋼生産量（B0シナリオ）

う。転炉鋼要求量が減少するため, よりシナリオごとの 転炉鋼と 2030 年と 2050 年の製鋼法別鉄鋼消費量を見る と, F010R1SD0 シナリオの大幅な伸びは電炉鋼によるも のであることが分かる（図-5）．

F000R0 シナリオも，転师鋼と鉄鋼消費量ともに，需 給バランスを考慮しないシナリオではあるが， F010R1SD0 シナリオではスクラップの地域内消費を優先 させるため, F000R0 シナリオと比較して世界の中で電 炉鋼生産に優位性が生じ生産量が伸びるている．また， F110R1SD1 と F111R1CD1 シナリオは, 双方とも鉄鋼の 需給バランスを取ろうとするシナリオなのでが, F110R1SD1 シナリオでは，スクラップの国内消費を重要 視するため電炉鋼消費量が F111R1CD1 シナリオと比心 て大きくは減少していない. また，F000R0 シナリオは 国内需給は考慮せず世界動向により生産量を決定してい るため, 緩やかに増加する世界の鉄鋼消費量に合わせて 電炉鋼生産量も伸びており，スクラップの国内消費を目 指す F110R1SD1 シナリオより電炉鋼生産量が多くなつ ている.

転炉鋼生産量は，2030年には1,087万トンの差があるも のの2050年にはその差は549万トンにまで縮まっており， いずれのシナリオも2005年の約半分となる.

\section{c）世界における日本の位置付け}

鉄鋼生産量の世界に占めるシェアは, 2005 年以降中 国の台頭により 2005 年の $11.4 \%$ から 2012年の 6.9\%に急 激に減少してきた。世界全体での鉄鋼生産量が増加する 中, 鉄鋼生産量は減少傾向にあるため, シェアも減少傾 向となり（図-6），鉄鋼生産量合計では, F000R0 と F010R1SD0 シナリオでは 4.9\%, 他の二つのシナリオで は 3\%前後となる. 2035 年頃に鉄鋼生産量が増加する F010R1SD0 シナリオであっても，シェアとしては大きく 伸びておらず，7\%程度を維持するに留まっている.

一方で，日本において比較的技術優位性がある転炉鋼 においては，世界に占めるシェアは，鉄鋼生産量合計と 比べてやや高いものの F000R0 と F111R1CD1 シナリオで 

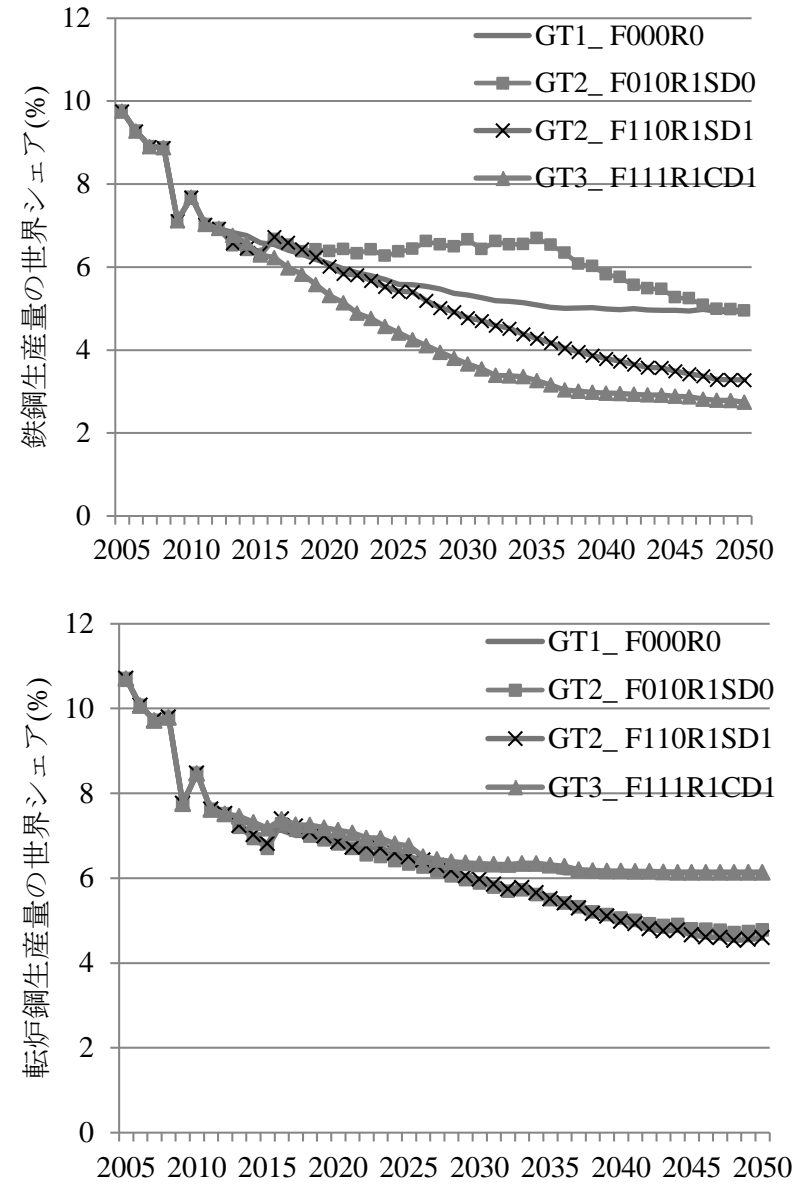

図-6 鉄鋼生産量の世界に占めるシェア

(上 : 鉄鋼全量, 下 : 転炉鋼)

6.1\%程度であり, 他の二つは 4\%後半にまで減少する. 鉄鋼生産量であっても，転炉鋼生産量の夕をみても， 世界に占める日本のシェアは, 本研究で想定したシナリ オでは大きく伸びることはないことが確認された.

B0シナリオの場合のみを例として取り上げたが，B1 シナリオの場合，世界全体での転炉鋼要求量が減少寸る ので，それに伴い各国の転炬鋼生産量も減少寸る，世界 で全体的に減少するので，シェアでみると，B0シナリ オの場合との違いは1\%に満たなかった.

\section{4. まとめ}

本研究では, 財の貿易シナリオ, 転炉鋼要求シナリオ, および，製鋼法選択シナリオを設定することで，世界の 生産動向に複数の想定をおき，その条件下で日本の製鋼 法別鉄鋼生産量が取り得る幅について2012年から2050年 までの推計を行った.

・2050年の日本の鉄鋼消費量は，世界の財の生産シェア を基準年で固定したGT1シナリオで最も大きくなり， 5,279万トンであった。他の二つのシナリオは大きな
差がなく，最小値は4,327万トンであった.

-鉄鋼生産量に対し, 財の貿易シナリオや転炉鋼要求シ ナリオの影響は大きくなく，製鋼法選択シナリオが最 も影響を与えた。

・鉄鋼生産量は，スクラップを国内でできるだけ消費 し，かつ，鉄鋼の需給バランスは考慮しない F010R1SD0シナリオで最も多くなり，2035年には1.49 億トンに達した．ただし，2050年には1.20億トンにま で減少する. 増加の要因は, スクラップ余剩により電 炉鋼生産が増加したことによる。

・鉄鋼生産量の幅の中で最小值をとるのは転炉鋼，鉄鋼 全量ともに需給バランスをとるよう生産調整する F111R1CD1シナリオであった.

・世界の鉄鋼生産に占める日本のシェアは，いずれのシ ナリオでも減少傾向にあり，鉄鋼全体では2.0〜 4.2\%， 転炉鋼のみでは1.4〜2.9\%のシェアの減少となった.

本研究では, 日本の鉄鋼生産量に対し, 不確実性を含 みながらも取り得る最大限の幅を検討することを目的と した．政府の検討においても，現時点で考えられる社会 の方向性を踏まえたシナリオコンセプトを設定し，それ ぞれの社会のメリットおよびデメリットについて整理す るために, 2050年に想定しうる5つの社会2)が検討される など，幅のある社会像を検討している．本研究にて想定 したシナリオでの鉄鋼生産量を排出削減目標検討におい て所与の条件として利用寸ることで, 将来社会の不確実 性を考慮することが可能となり, 有用な科学的知見とな る．仮に日本が国内で発生する資源はできるだけ活用し， かつ，技術優位性を今後も保っていくような将来像に向 けて社会を誘導していこうとする場合には，GT2F110R1SD1シナリオの鉄鋼生産量を所与とし，その条件 下で二酸化炭素排出量の削減目標達成にむけた対策を検 討することになろう。

ただし，本研究では議論を整理するため，表-3に示し た因子のみを考慮し，世界各地域が各シナリオにおいて， 同条件下では同様の選択をすることを想定した。 世界に おける鉄鋼生産の分配では，二酸化炭素排出量も重要な 要素であり，これに関連するエネルギー効率やCCSの容 量なども生産量を決定する因子となり得て，同じ条件下 でも各地域が異なった選択をする可能性がある。また， 二酸化炭素排出量を最小とする分配は，世界全体での最 適解の一つとして提示寸る意義がある. 今後の課題とし ては，これらの要素を取り込んだシナリオも考慮し，各 地域のエネルギー消費量をもとに鉄鋼部門における二酸 化炭素排出量削減の可能性を検討することが挙げられる. 
謝辞 : 本研究は，環境省環境研究総合推進費 2-1402「わ が国を中心とした温室効果ガスの長期削減目標に対応す る緩和策の評価に関する研究」及びJSPS科研費 25870361 による研究成果の一部である.ここに示し謝意を表す る.

\section{参考文献}

1) 経済産業省長期エネルギ一需給見通し小委員会: http://www.enecho.meti.go.jp/committee/council/basic_policy _subcommittee/ （アクセス日 : 2015.06.18)

2) 環境省:2013年以降の対策・施策に関する報告書 https://funtoshare.env.go.jp/roadmap/from2013.html（アク セス日 : 2015.06.18)

3) 東章吾, 河瀬玲奈, 松岡譲: サービス需要を考慮した世界 の鉄鋼需要量に関する研究，土木学会論文集 $G$ (環境)， Vol.68, No.5, I15-I24, 2012.

4) World Steel Association (worldsteel), Steel Statiatical Yearbook 2014, World Steel Association, 2014.

5) Hidalgo I., Szabo L., Calleja I., Císcar J. C., Russ P., Soria A .: Energy consumption and $\mathrm{CO}_{2}$ emissions from the world iron and steel industry, European Communities, Report EUR 20686EN, 2003.

6) worldsteel : The Future of the Global Steel Industry.-Challenges and Opportunities, IMnl 39th Annual Conference, 2013.
7) 河瀬玲奈，松岡譲: 2050 年における世界の鉄鋼部門からの $\mathrm{CO}_{2}$ 排出量削減ポテンシャルの推計，土木学会論文集 $G$ (環境)，環境システム 2014

8) Intemational Energy Association (IEA): Energy Techonology Perspective 2014, IEA, 2014.

9) 京都大学: 平成 26 年度環境研究総合推進費「わが国を中 心とした温室効果ガスの長期削減目標に対応寸る緩和策 の評価に関する研究（(5)社会におけるエネルギー集約素 材の蓄積からみた将来シナリオの検討）」による研究委 託業務，2014年 2 月.

10) FOURIN: 世界自動車統計年刊 2013, 2013.

11) 日立: 鉄道システム事業戦略，2014年 6 月.

12) 日本造船工業会: 造船関係資料 2014年 3 月， 2014.

13) Fujimori S., Masui T., Matsuoka Y: Global low carbon society scenario analysis based on two representative socioeconomic scenarios. Global Environmental Research, 17 (1), 79-87, 2013.

14) worldsteel :Fact Sheet-The three Rs-, 2011.

15）東京製鐵株式会社: 低炭素型 $3 \mathrm{R}$ 技術・システム実証事業 (鉄スクラップの自動車部品への高度利用化技術調査) 報告書, 2015 .

16) 日本鉄鋼連盟: 鉄鋼統計要覧，各年版

17) 特殊鋼俱楽部: 特殊鋼の最終用途別需要実態調査

18) World steel association :Fact Sheet-Raw materials-, 2010.

(2015.4.7 受付)

\title{
Steel Production Estimation in Japan with Considering Global Market
}

\section{Reina KAWASE ${ }^{1}$ and Yuzuru MATSUOKA ${ }^{1}$}

\author{
${ }^{1}$ Dept. of Environmental Engineering, Graduate School of Engineering, Kyoto University
}

Steel productions from 2012-2050 in Japan were estimated under various global assumptions based on combination $n$ of scenarios such as goods trade scenarios and process selection scenarios. Process selection scenarios decide volume of steel production by process with considering steel consumption projection, supply-demand balance of steel, and scrap surplus. The range of steel production by process was analyzed.

Maximum steel production was estimated under the scenario which consumes scrap in domestic steel production at maximum level. In 2035, steel production reaches 149 million ton because of increase in electric furnace steel. It, however, decreases towards 2050 and amounts to 120 million ton. Minimum steel production is under the scenario which assumes technology progress in steel making and supplydemand balance consideration in each region. Steel production decreases from base year and is 44 million ton in 2050. 